\title{
Assessment of Environmental Impact and Economic Viability of Domestic Biogas Plant Technology in Bangladesh
}

\author{
Suraya Akter ${ }^{1}$, Humayun Kabir ${ }^{1}$, Shamima Akhter ${ }^{1} \&$ Md. Mehedi Hasan ${ }^{2}$ \\ ${ }^{1}$ Department of Agricultural Economics, Bangladesh Agricultural University, Mymensingh, Bangladesh \\ ${ }^{2}$ Department of Medicine, Faculty of Veterinary Science, Bangladesh Agricultural University, Mymensingh, \\ Bangladesh \\ Correspondence: Shamima Akhter, Department of Agricultural Economics, Bangladesh Agricultural University, \\ Mymensingh 2202, Bangladesh. Tel: 880-172-689-9326. E-mail: s.akhter_bau@yahoo.com
}

Received: July 7, $2021 \quad$ Accepted: August 2, $2021 \quad$ Online Published: August 20, 2021

doi:10.5539/jsd.v14n5p44 URL: https://doi.org/10.5539/jsd.v14n5p44

\begin{abstract}
The study investigated the distinct environmental impacts and economic viability of domestic biogas technology in the countryside of Bangladesh. The study was carried out by a survey through personal interviews with biogas users. Seventy households were selected purposively and interviews were conducted through semi-structured questionnaires. The study mainly highlighted the potential reduction of greenhouse gas (GHG) emission and economic benefits of biogas utilization which were evaluated considering the substitution of traditional biomass fuels, by saving Liquefied Petroleum Gas (LPG) and cost of chemical fertilizer, and carbon trading. The economic benefits are addressed using some well-known economic indicators like Net Present Value (NPV), Payback Period (PBP), and Benefit-Cost Ratio (BCR). The results of the study revealed that a small-scale household anaerobic cow dung biogas digester not only exhibited the potential to cut carbon emissions on average by about 7.8 tons of $\mathrm{CO}_{2}$ equivalents yearly, but it also demonstrated the economic feasibility of doing so as the value of NPV and BCR was positive. This study recommends that the government approach, awareness program, and continuous and proper performing of the biogas technology are needed to intensify the multiples environmental benefits of the technology.
\end{abstract}

Keywords: biogas, domestic digester, cow dung, bio-slurry, GHG emission, economic evaluation

\section{Introduction}

Energy, undoubtedly, is a pre-requisite for an entire nation's economic activities and social development (Ahiduzzaman and Islam, 2011; Rajendran et al., 2012; Uddin and Taplin, 2006), and one of the most crucial strategic commodities has long been the energy that has direct linkages with economic security, social security and environmental sustainability (Abbas et al., 2017; Ahuja and Tatsutani, 2009; Amin, 2015).

Bangladesh is one of the energy poverty (limited electricity and smoky cooking systems) (Khan et al., 2014; Rahman et al., 2014) and the world's most densely populated countries. In the country, about 116 million people ( $72 \%$ of the total population) live in rural areas (Amin and Rahman, 2019). About $47 \%$ and $6 \%$ of people in Bangladesh have access to electricity and natural gas, respectively, however, the service is not at a satisfactory level even though the government has also started importing Liquefied Petroleum Gas (LPG) and Liquefied Natural Gas (LNG) to meet the demand for household energy consumption. But importing LPG and LNG may not be an optimal long-term solution in the context of Bangladesh (Amin and Rahman, 2019). Furthermore, there is no natural gas pipeline connection throughout the rural and remote areas of the country. As a result, the rural people use traditional biomass energy sources for cooking (i.e., firewood, agricultural waste, and cow dung, etc.), which is about $62 \%$ of total energy consumption in Bangladesh (Foysal et al., 2012; Khan et al., 2014). However, direct combustion of biomass caused serious environmental degradation problems such as indoor air pollution, deforestation, and superfluous emissions of tons of greenhouse gas (GHG) which affects the environment locally and globally (Abbas, 2013; Katuwal and Bohara, 2009; Yu et al., 2008). As a result, the country's environmental well-being continues to be harmed by the widespread use of conventional biomass fuels for cooking (Mengistu et al., 2016).

Biogas, a renewable energy source, has become popular not only for the substitution of other fuels but also for 
environmental and socio-economic benefits (i.e., preventing deforestation, reducing the necessity of purchasing fuel for cooking, the reduction of odor, the manufacturing of bio-slurry as a fertilizer replacing the chemical fertilizer, and limiting the GHG emissions) (Bentzen et al., 2018; Bruun et al., 2014; Gabisa and Gheewala, 2019; Gautam et al., 2009; Haryanto et al., 2017; Iqbal et al., 2014; Mengistu et al., 2016; Yu et al., 2008). Biogas is comprised of $60 \%-70 \%$ methane $\left(\mathrm{CH}_{4}\right)$ and $30 \%-40 \%$ carbon dioxide $\left(\mathrm{CO}_{2}\right)$ produced by waste materials, particularly, cow dung. Subsequently, it is adopted as a least-cost technology with its diverse advantages such as a waste recycling tool, and production of clean energy and bio-fertilizer (Katuwal and Bohara, 2009; Kinyua et al., 2016; Rahman et al., 2014; Rahman et al., 2018). Most of the biogas plants in Bangladesh are built based on smallscale cattle farms that only used their cow dung in the plants (Khan and Martin, 2016; Rahman et al., 2017). At present, cow dung available from 24.48 million cattle is nearly 244.8 million tons (10 kg per cattle per day) in Bangladesh (Amin and Rahman, 2019; Gofran, 2004). According to the Institute of Fuel Research and Development, our country has a potential of about 4 million biogas plants that can produce 105 billion cubic feet of biogas annually, which is the same as 1.5 million tons of kerosene or 3.08 million tons of coal (Iqbal et al., 2014). But unfortunately, the majority of farmers in Bangladesh simply gather the manure and stack it near the pens. After six months, the manure is collected and dispersed on the fields to be utilized as compost. This traditional use of dung has a big impact on the environment and cultivable land in Bangladesh because, during the stacking stage, an anaerobic process occurs inside the stacked dung, emitting methane as well as a foul odor, dust, and polluting of surface water (Salam et al., 2018). Thus, Bangladesh has huge potentials for developing biogas technologies in rural areas and one major benefit of anaerobic digestion (AD) is to mitigate GHG emissions from cow dung and other sources even from traditional biomass burning (Ghimire; Iqbal et al., 2014). In addition, Bangladesh can earn foreign currency through the Clean Development Mechanism (CDM) under the Kyoto Protocol by reducing GHG emissions using biogas.

There are around a dozen related peer-reviewed studies from Africa and Asia that are particular to the environmental consequences of household biogas technology (BT) at the global level (Amare, 2014; Gabisa and Gheewala, 2019; Haryanto et al., 2017; Hou et al., 2017; Katuwal and Bohara, 2009; Lansche et al.; Laramee and Davis, 2013; Mengistu et al., 2016; Pathak et al., 2009; Shane and Gheewala, 2017; Yu et al., 2008; Zhang et al., 2013). China is a leading country that inaugurated the utilization and benefits of BT; most of their studies were focused on the estimation of GHG reduction by energy substitution. It was reported by some authors that a domestic biogas plant can reduce the GHG emission with a range from 1.3 to 9.7 tons of $\mathrm{CO}_{2}$ equivalents $\left(\mathrm{CO}_{2} \mathrm{e}\right)$ (Katuwal and Bohara, 2009; Laramee and Davis, 2013; Pathak et al., 2009; Zhang et al., 2013). Furthermore, several studies estimated the GHG emission reductions considering the final energy uses rather than the entire life cycle of a biogas plant (Amare, 2014; Lansche et al.; Mengistu et al., 2016).

At the national level, Mainali et al. (2017) estimated the GHG emissions reduction potential of a layer poultry farm through BT using the poultry litter. Rahman et al. (2017) conducted a study on GHG mitigation capacity of small-scale BT using cow dung which estimated 11 tons $\mathrm{CO}_{2}$ e per year from cow dung and bio-slurry. However, there is a paucity of empirical evidence on the environmental effects such as GHG emission reduction from cow dung used in biogas plants in Bangladesh. To the author's knowledge, there is no published data of GHG emission mitigation through BT considering biomass fuel and LPG burning in Bangladesh. Therefore, the study aimed to investigate the overall GHG mitigation capacity and economic viability of domestic biogas plant technology in Bangladesh.

\subsection{Description of the Study Area}

The research was conducted from January to June in 2019 purposively in two Upazilas (sub-districts), Gabtali and Shibganj, of Bogra district in the north of Bangladesh, which were are-based rural areas where there are no natural gas supply pipelines. Bogra district is located approximately between $24^{\circ} 69^{\prime}$ North latitudes and $89^{\circ} 45^{\prime}$ East longitudes. Most of the rural population was involved in semi-subsistence agriculture, and households typically own at least one dairy cattle, commonly stabled both day and night, and practice integrated farming methods where manure is used for crop production. Non-Governmental Organizations (NGOs) performances were intensive on implementing family-scale biogas plants in the region. Additionally, maximum households involved with biogas production using an average of only four cows dung daily in the study areas.

\section{Method}

The study incorporated data on bioenergy and biogas potentials from earlier studies published in Bangladeshi and other international journals. In addition, some equations and calculations that were performed in different studies to determine the available potential were used to assess environmental and social impacts. Field surveys were also conducted to acquire some of the data for the existing biogas facilities. Finally, we estimated the GHG emissions 
potential and their reduction prospects, using the equations, with collected field data from the studied sites.

To avoid any misinterpretation, questions were first formulated with respondents' perspectives in mind. Second, jargon, slang, ambiguity, uncertainty, emotional language, prestige biases, double-barreled questions, frightening questions, incorrect premises, and double negatives were avoided during questionnaire development. Ten interviews were conducted before the real data was collected to pre-test the correctness of the interviewing schedule. During pre-testing, certain errors were discovered. As a result, a few changes were made to improve the authenticity of the data collected. The researcher double-checked each interview schedule for probable inaccuracies and missing entries. We avoided any bias of findings in such ways.

\subsection{Data Collection}

A survey was conducted purposively with a total of 70 biogas users' households through a semi-structured questionnaire. The purposive data were gathered from both primary and secondary sources. Face-to-face interviews were conducted to collect primary data. The questionnaire decorates on costs and benefits of a biogas plant, current, and past fuel use, various perceptions (knowledge, attitude, preference) of biogas users, application of biogas and bio-slurry, and environmental issue of community. Some of the data were acquired from appropriate research and relevant office records and reports, published journals, Statistical Yearbook of Bangladesh, Bangladesh Economic Review, Department of Livestock Service, and NGOs. Various conversion determinants were also gathered from a variety of secondary data sources. The survey's purpose was to determine the household satisfaction level with the technology employed, bottlenecks encountered during plant operation, and the amount of bio-slurry used as a by-product. For analysis, variables and their categories were coded.

\subsection{Biogas Generating System in Studied Areas}

The fixed dome digester model, also known as the Indian model, was used in the studied area, with a digester at the bottom and a non-transferable gasholder at the top. After gathering more slurry, farmers applied it to the cropland. The moisture content (> 80\%) of bio-slurry makes it ideal for growing vegetables all year. Usually, for producing biogas, household members manually mixed cow dung and water in the mixing tank, which is collected from the barn and brought from the motor or tube well respectively. In most of the households, the digester was placed close to the barn so that the cow manure could straightforwardly be directed to it after cleaning the shed. The biogas is transported to the house's biogas stoves via a plastic pipe. It was settled adjacent to the house to save the money on piping and gas lost during transfer. The gas is used during cooking which replaces the previously utilized fuels (i.e., cow manure, wood, and residues). The bio-slurry produced as a by-product replaces an equivalent quantity of chemical fertilizer and lowers emissions connected with its manufacturing and application. The biogas produced replaces an equivalent amount of biomass fuel, resulting in lower emissions from biomass burning.

\subsection{Quantification of Fuel Saved by Biogas Utilization}

During the interview, daily biomass (firewood, residues, and cow dung) use by all sample households was recorded at amounts that are used for cooking per month in absence of biogas digesters and then estimated the total amount of biomass used in a year multiplied by the market price of fuelwood showed the total cost of fuel consumption of each household and also measured the emission of fuelwood that caused climate change. Liquefied petroleum gas (LPG) was self-reported by respondents. Replacement of LPG by household biogas digesters provided economic benefits of a biogas plant in the study areas.

\subsection{GHG Emissions Potential}

Only the most potent GHGs (i.e., $\mathrm{CO}_{2}, \mathrm{CH}_{4}$, and $\mathrm{N}_{2} \mathrm{O}$ ) were considered to calculate $\mathrm{GHG}$ emission reductions ( $\mathrm{Yu}$ et al., 2008). This study used the global warming potentials (GWP) of these gases over a 100-year time horizon, which were modified into 1, 25, and 298 in the fourth assessment report, respectively (IPCC, 2007).

\subsubsection{GHG $\left(\mathrm{CH}_{4}\right)$ Emissions from Cow Dung Management in Studied Areas}

Emissions that are mostly generated are methane from cow dung which is used in producing biogas at each of its life cycle stages. IPCC (2006) volume 4 chapter 10-guideline was used in estimating the emissions from cow dung. Methane is emitted at different stages of biogas production. At first, the methane starts to be emitted during the natural process of digestion by the livestock, which is called enteric fermentation followed by emissions during cow dung management. The emission from enteric fermentation is avoided here since there is no method to limit the emission from normal metabolic activities. The emission during cow dung management was calculated using the equation (1).

$$
\mathrm{E}_{\mathrm{CO}_{2} \mathrm{e}}=\mathrm{YC} \times \mathrm{P}_{\mathrm{CH}_{4}} \times \mathrm{GWP}_{\mathrm{CH}_{4}}
$$


Source: (Mengistu et al., 2016): pp.134

Where: $\mathrm{Eco}_{2} \mathrm{e}=$ Average annual emission of methane from the biogas digesters in $\mathrm{kg}$ of $\mathrm{CO}_{2} \mathrm{e} ; \mathrm{YC}=$ Yearly average biogas generation value from the digester size in $\mathrm{kg}$, given the daily average biogas generation $=1.2 \mathrm{~m}^{3}$ (Khan and Martin, 2016), and $1 \mathrm{~m}^{3}$ biogas $=0.7 \mathrm{~kg}$ (Pathak et al., 2009); $\mathbf{P}_{\mathbf{C H} 4}=$ methane's volume fraction in biogas, which is about $60 \%$ (Mengistu et al., 2016); $\mathrm{GWP}_{\mathbf{C H} 4}=\mathrm{GWP}$ of methane in $\mathrm{CO}_{2} \mathrm{e}$ which is 25 (IPCC, 2007).

Secondly, methane might be released during the digestion of cow dung in the biogas generating system. As anaerobic digestion has occurred and methane emissions are prevented here, the only leakage is considered an emission. The following equation (2) is how the leakage was estimated:

$$
\mathrm{CH}_{4}=\mathrm{CH}_{4} \text { Produced } \times\left(\frac{1}{C E}-1\right)
$$

Source: (Feng et al., 2009; IPCC, 2006)

Where: $\mathrm{CH}_{4}$ produced $=$ Biogas production in a digester per year, $\mathrm{m}^{3} \mathrm{y}^{-1}$ and $\mathrm{CE}=$ Methane collection efficiency [0.975 for fixed dome (IPCC, 2006)].

\subsubsection{GHG $\left(\mathrm{CO}_{2}\right)$ Emissions from Fertilizers in Cropland}

$\mathrm{CO}_{2}$ emissions are reduced when bio-slurry is used instead of chemical fertilizer that would otherwise be produced by fertilizer use. The $\mathrm{CO}_{2}$ emission was computed using the following equation (3). In addition, biogas slurry saves the use of nitrogen $(\mathrm{N})$ fertilizer which would reduce the emission of nitrous oxide $\left(\mathrm{N}_{2} \mathrm{O}\right)$, which is also evaluated.

$$
\mathrm{Eco}_{2} \mathrm{e}=\left(\mathrm{N} \times \mathrm{GWP}_{\mathrm{N}}\right)+\left(\mathrm{N} \times \mathrm{N}_{2} \mathrm{O}-\mathrm{N} \times \mathrm{GWP}_{\mathrm{N} 2 \mathrm{O}}\right)+\left(\mathrm{P} \times \mathrm{GWP}_{\mathrm{P}}\right)+\left(\mathrm{K} \times \mathrm{GWP}_{\mathrm{K}}\right)
$$

Source: (Haryanto et al., 2017; Pathak et al., 2009): pp. 413, 32

Where: $\mathrm{Eco}_{2} \mathrm{e}=$ Emission of $\mathrm{CO}_{2} \mathrm{e}$ from fertilizer; $\mathrm{N}=$ Amount of nitrogen fertilizer; $\mathrm{GWP}_{\mathrm{N}}=$ Global warming potential for $\mathrm{N}$ production $\left(\mathrm{CO}_{2} \mathrm{e} / \mathrm{kg}\right) ; \mathrm{N}_{2} \mathrm{O}-\mathrm{N}=\mathrm{N}_{2} \mathrm{O}$ emission factor for $\mathrm{N}$ application $(\mathrm{kg} / \mathrm{kg}) ; \mathrm{GWP}_{\mathrm{N} 2} \mathrm{O}=$ Global warming potential for $\mathrm{N}_{2} \mathrm{O}\left(\mathrm{CO}_{2} \mathrm{e} / \mathrm{kg}\right) ; \mathrm{P}=$ Amount of phosphorous $(\mathrm{P})(\mathrm{kg} / \mathrm{Y}) ; \mathrm{GWP}=$ Global warming potential for $\mathrm{P}$ production $\left(\mathrm{CO}_{2} \mathrm{e} / \mathrm{kg}\right) ; \mathrm{K}=$ Amount of potassium $(\mathrm{K})(\mathrm{kg} / \mathrm{Y}) ; \mathrm{GWP}_{\mathrm{K}}=$ Global warming potential for $\mathrm{K}$ production $\left(\mathrm{CO}_{2} \mathrm{e} / \mathrm{kg}\right)$.

\subsubsection{GHG $\left(\mathrm{CO}_{2}\right)$ Emission from Traditional Fuel Use}

$\mathrm{CO}_{2}$ emissions from biomass combustion: The quantity of $\mathrm{CO}_{2}$ emitted to the environment is determined by the type of fuel used as an energy source (Junior and Bank, 2017). So, emissions from the traditional burning of manure and firewood were calculated using equation (4).

$$
C E_{i}=\sum_{i=1}^{n} Q_{i} \times C_{i} \times O_{i} \times \frac{44}{12}
$$

Source: (Gabisa and Gheewala, 2019): pp.450

Where: $\mathrm{CE}_{\mathbf{i}}=\mathrm{CO}_{2}$ emissions from biomass resource (ton $\mathrm{CO}_{2}$ ), $\mathrm{Q}_{\mathrm{i}}=$ Quantity of biomass resource consumed (ton), $\mathrm{C}_{\mathbf{i}}=$ Carbon emission factor of biomass type, $\mathrm{O}_{\mathbf{i}}=$ Carbon oxidation rate of biomass type (\%). Carbon emission factors and the rates of carbon oxidation are shown in Table 1.

Table 1. Carbon emission factors and the rates of carbon oxidation of different biomass fuels

\begin{tabular}{lll}
\hline Biomass type & Carbon emission factor & Carbon oxidation factor \\
\hline Firewood & 0.45 & 0.87 \\
Dung & 0.40 & 0.85 \\
Residue & 0.39 & 0.85 \\
\hline
\end{tabular}

Source: (Pei-dong et al., 2007; Shane and Gheewala, 2017)

$\mathrm{CO}_{2}$ emissions from LPG usage: $\mathrm{CO}_{2}$ emissions from the yearly consumption of non-renewable energy fuels such as LPG were derived from equation (5). The results of the emissions were expressed in $\mathrm{kg} \mathrm{CO}_{2} \mathrm{e}_{\text {household }}{ }^{-1} \mathrm{year}^{-1}$. The heating value and emission factors used for non-renewable fossil fuels are presented in (Table 2). 
Source: (Baul et al., 2018): pp.602

$$
C E_{i}=\sum(E F \times \text { Activity })
$$

Where $\mathrm{CE}_{\mathbf{i}}=\mathrm{CO}_{2}$ emissions from LPG burning, $\mathrm{EF}=$ Emission factor of the LPG, Activity $=$ Amount of LPG consumed $(\mathrm{kg})$ in a year

Table 2. Heating value and emission factors used for non-renewable fossil fuel

\begin{tabular}{lll}
\hline Non-renewables & Heating value & Emission factor a $\left(\mathrm{kg} \mathrm{CO}_{2}\right.$ eq kWh-1) \\
\hline LPG & $6.66 \mathrm{kWh} \mathrm{l}^{-1}$ & 0.241 \\
\hline
\end{tabular}

Source: (IEA, 2010)

\subsection{Life Cycle of GHG Emission Reduction}

Biogas as a biomass energy substitute minimizes GHG emissions throughout its life cycle in rural households. With the substantial role of bio-slurry, the quantity of chemical fertilizer required on farms is reduced when biomass energy sources are replaced. As a result, it can be expressed as an equation (6).

Source: (Gabisa and Gheewala, 2019): pp.450

$$
G H G_{\text {red }}=\left(G H G_{C M}+G H G_{F A}+G H G_{F C}\right)
$$

Here: $\mathrm{GHG}$ red= GHG emission reduction, ton $\mathrm{CO}_{2} \mathrm{eq}^{-1}$, GHG $\mathrm{GH}_{\mathrm{C}}$ : GHG emission from cow dung management, ton $\mathrm{CO}_{2}$ eq $\mathrm{y}^{-1}$, GHGFA $=\mathrm{GHG}$ emission from fertilizer application, ton $\mathrm{CO}_{2} \mathrm{eq}^{-1}$, GHGFC $=$ GHG emissions from fuel (biomass and LPG) burning, ton $\mathrm{CO}_{2} \mathrm{eq}^{-1}$.

\subsection{Economic Analysis of Biogas Production}

The construction of biogas digesters in rural areas has the potential to not only generate renewable energy but also to assist households by assuring a cleaner environment, better disease control, and economic growth (Gabisa and Gheewala, 2019). Economic evaluation through cost-benefit analysis is a widely used analytical tool for comparing the benefits and costs of interventions (Hutton et al., 2007). Different academics utilize several variables to assess the economic sustainability of rural household biogas plants. The majority of the researchers evaluated the system using well-known economic concepts like Benefit-Cost Ratio (BCR), Net Present Value (NPV), and Payback Period (PBP) (Gabisa and Gheewala, 2019).

\subsubsection{Benefit-Cost Ratio (BCR)}

A digester's BCR is used to analyze whether or not a project is cost-effective. The project is economically viable if the BCR is bigger than unity. It will also assess the project's overall financial impact, which we can all understand. The project's expenses and benefits were calculated. A constant price method was employed to calculate future costs and benefits, which assumes that present benefit and cost prices will remain constant. It is a valid measure for calculating future costs and benefits since inflation will affect most prices in the same way, preserving the relative relationship between prices. The BCR was calculated using a discount rate of $12 \%$, and the economic life of the BT was estimated to be 15 years by IDCOL and SNV. In Bangladesh, the data on discount rates is not uniform. As a result, a 12\% rate was employed for analysis following the current literature (Kabir et al., 2012). We ran an NPV analysis before computing the BCR, taking into account the benefit-cost analysis estimation's temporal dynamics.

The economic benefits derived from LPG saving, traditional biomass consumption cost-saving, chemical fertilizer saving and, earning revenue from the carbon credit scheme reducing $\mathrm{CO}_{2} \mathrm{eq}$ emission yearly. The initial investment cost, as well as operations and maintenance expenditures, are incurred for the domestic BT. The BCR can be expressed as:

$$
\text { Benefit-Cost Ratio }=\frac{\sum_{t=1}^{n} \frac{B_{n}}{(1+i) n^{n}}}{\sum_{t=1}^{n} \frac{C_{n}}{(1+i)^{n}}}
$$

Source: (Abbas et al., 2017; Gabisa and Gheewala, 2019): pp.451, 433

Where: $B_{n}=$ Yearly benefit; $C_{n}=$ Yearly cost; $\mathrm{i}=$ Rate of interest, $\mathrm{n}=$ Number of years. 


\subsubsection{Net Present Value (NPV), Payback Period (PBP)}

The terms NPV and PBP are commonly used to assess a project's economic viability. The NPV is used to determine if a project is profitable or not; if the NPV is positive, the project is economically viable.

$$
\mathrm{NPV}=\left[\sum_{t=1}^{n} \frac{C F_{t}}{(1+i)^{t}}\right]-I_{0} \quad \text { or } \quad \mathrm{NPV}=\left[\sum_{t=1}^{n} \frac{T A B_{b}-A O T_{C}}{(1+i)^{t}}\right]-I_{0}
$$

Source: (Kabir et al., 2012)

Where, $C F_{t}=$ Cash flow in year $\mathrm{t} ; \mathrm{TAB}_{\mathbf{b}}=$ Annual benefits; $\mathrm{AOT}_{\mathbf{c}}=$ Annual operating costs; $\mathrm{n}=$ Project life time; $\mathrm{i}=$ Discount rate; and $I_{0}=$ Initial investment cost.

The payback period (PBP), which shows us how long it will take to return the initial investment cost, is another economic indicator used to measure the project's economic viability.

$$
P B P=\frac{\text { Initial Investment }}{\text { Annual Operational Cash Flow }}
$$

Source: (Gabisa and Gheewala, 2019): pp. 451

\section{Results and Discussion}

The study's findings revealed that a small-scale domestic anaerobic cow dung biogas digester can reduce carbon emissions by around 7.8 tons of $\mathrm{CO}_{2}$ equivalents in a year. It also showed that doing so is economically feasible since both the NPV and BCR were positive. The detail of GHG emissions reduction and the economic analysis of the study is discussed in the results and discussion part.

\subsection{GHG Emissions, and Mitigation}

\subsubsection{GHG (Methane) Emission from Cow Dung Management}

Cow dung produces the most potent global warming $\mathrm{GHG}$ is methane $\left(\mathrm{CH}_{4}\right)$. And the technology can successfully reduce the emission of methane from cow dung in the open pit by transforming it as a raw material into biogas digesters. A common size of small-scale biogas digester $\left(2.4 \mathrm{~m}^{3}\right)$ required at least four cows which can generate on an average $1.2 \mathrm{~m}^{3}$ biogas daily (IRENA, 2016; Khan and Martin, 2016).

Thus, the average annual methane emissions from the $2.4 \mathrm{~m}^{3}$ biogas digesters were $4599 \mathrm{~kg} \mathrm{CO}_{2} \mathrm{eq}$ in the considered areas, which is currently avoided by regulating the manures in the digester. Another source of methane emission is leakage during the biogas generation phase, and the fixed dome digester's methane collection efficiency is 0.975 . A total of $117.918 \mathrm{~kg}$ of methane was estimated to have spilled from the digester and therefore, 8.254 tons of methane were being leaked from the 70 digesters. However, the biogas plant reduces on average 4.48 tons of $\mathrm{CO}_{2} \mathrm{e}$ per year. This can be the most compelling argument for the highest GHG emissions from the technical use of cow manure, which are mitigated by BT.

\subsubsection{GHG Emissions from Chemical Fertilizer Application in Cropland}

The household biogas digester with 4 cattle can produce $4230 \mathrm{~kg}$ dung (dry weight) per annum (Table 3 ). The biogas digester generates annually $1692 \mathrm{~kg}$ carbon (C) of bio-slurry [C content in slurry ( $\mathrm{kg} \mathrm{kg}-1$ dry wt.) is 0.4 , (i.e. 1692)] which substitutes $59 \mathrm{~kg} \mathrm{~N}, 42 \mathrm{~kg}$ phosphorus (P), and $33 \mathrm{~kg}$ potassium (K) fertilizer respectively, was calculated based on $\mathrm{N}$ content in slurry ( $\mathrm{kg} \mathrm{kg}-1$ dry wt.), $\mathrm{P}$ content in slurry ( $\mathrm{kg} \mathrm{kg}-1$ dry wt.), $\mathrm{K}$ content in slurry ( $\mathrm{kg} \mathrm{kg}-1$ dry wt.) are $0.014,0.01$ and 0.008 respectively. The production of these chemical fertilizers has GWP which is $214.74 \mathrm{~kg} \mathrm{CO}_{2}$ eqv., where $\mathrm{CO}_{2}$ emission for $\mathrm{N}, \mathrm{P}, \mathrm{K}$ fertilizer production $(\mathrm{kg} \mathrm{kg}-1)$ are $1.3,0.2,0.2$ respectively and $\mathrm{N}_{2} \mathrm{O}-\mathrm{N}$ emission from $\mathrm{N}$ fertilizer application $(\mathrm{kg} \mathrm{kg}-1)$ is 0.007 . Table 3 shows the global warming potential estimates for several sources that were used to calculate the decrease of GHGs emission reduction from a family-sized cow dung BT (Pathak et al., 2009). 
Table 3. Coefficients used for calculation of GHG emission potential of a household biogas plant

\begin{tabular}{|c|c|c|}
\hline Parameter & $\begin{array}{l}\text { Conversion } \\
\text { factor }\end{array}$ & Reference \\
\hline Average annual cow dung production per cattle (kg dry wt.) & 4230 & $\begin{array}{l}\text { Author's } \\
\text { calculation }\end{array}$ \\
\hline Methane content in biogas $(\%)$ & $60 \%$ & \multirow{9}{*}{$\begin{array}{l}\text { (Pathak et al., } \\
\text { 2009) }\end{array}$} \\
\hline $\mathrm{C}$ content in slurry ( $\mathrm{kg} \mathrm{kg}-1$ dry wt.) & 0.4 & \\
\hline $\mathrm{N}$ content in slurry ( $\mathrm{kg} \mathrm{kg}-1$ dry wt.) & 0.014 & \\
\hline$P$ content in slurry ( $\mathrm{kg} \mathrm{kg}-1$ dry wt.) & 0.01 & \\
\hline $\mathrm{K}$ content in slurry ( $\mathrm{kg} \mathrm{kg}-1$ dry wt.) & 0.008 & \\
\hline $\mathrm{CO}_{2}$ emission for $\mathrm{N}$ fertilizer production $(\mathrm{kg} \mathrm{kg}-1)$ & 1.3 & \\
\hline $\mathrm{CO}_{2}$ emission for $\mathrm{P}$ fertilizer production $(\mathrm{kg} \mathrm{kg}-1)$ & 0.2 & \\
\hline $\mathrm{CO}_{2}$ emission for $\mathrm{K}$ fertilizer production $(\mathrm{kg} \mathrm{kg}-1)$ & 0.2 & \\
\hline $\mathrm{N}_{2} \mathrm{O}-\mathrm{N}$ emission from $\mathrm{N}$ fertilizer application $(\mathrm{kg} \mathrm{kg}-1)$ & 0.007 & \\
\hline $\mathrm{GWP}$ of $\mathrm{CO}_{2}\left(\mathrm{~kg} \mathrm{CO} \mathrm{CO}_{2}\right.$ eqv. kg-1) & 1 & \multirow[t]{3}{*}{ (IPCC, 2007) } \\
\hline $\mathrm{GWP}$ of $\mathrm{CH}_{4}\left(\mathrm{~kg} \mathrm{CO} \mathrm{CO}_{2}\right.$ eqv. $\left.\mathrm{kg}-1\right)$ & 25 & \\
\hline GWP of $\mathrm{N}_{2} \mathrm{O}\left(\mathrm{kg} \mathrm{CO} \mathrm{CO}_{2}\right.$ eqv. $\left.\mathrm{kg}-1\right)$ & 298 & \\
\hline
\end{tabular}

Note. ${ }^{a}$ Cow dung productions (dry wt.) per cattle and buffalo are 1,100 and 1,350 kg year-1, respectively (Gaur); ${ }^{\mathrm{b}}$ Cow dung lost during collection (30\%) and used for construction (1-9\%) was deducted from total production (TERI, 2001).

Bio-slurry is utilized as a fertilizer on agricultural farmland in the studied site. In comparison to non-user households, biogas-user households (87 percent) stated that about half of the total purchase of chemical fertilizer is turned over using bio-slurry in the specified production year, whereas biogas-users could reduce about $50 \%$ fertilizer usage by using bio-slurry in China (Ding et al., 2012). There are few reports that bio-slurry cannot replenish nutrients to grow plants without using chemical fertilizers. Hence, the user households could have reduced at the minimum half of the fertilizer usage by proper utilization of bio-slurry. This, in succession, could have relieved the biogas-users mostly from purchasing overpriced chemical fertilizers and additionally reduced GHG emission by 15.03 tons of $\mathrm{CO}_{2} \mathrm{eq}$ (Uma, 2014).

The application of bio-slurry as a fertilizer boosts soil fertility by enhancing nutrient contents. The producing amounts of bio-slurry are varied with different digesters sizes. A correctly used domestic biogas can generate an average of 2.6 tons to 3.5 tons of solid bio-fertilizer yearly (Mengistu et al., 2016). In the study, the average bioslurry from $\left(2.4 \mathrm{~m}^{3}\right)$ biogas digester is 1.6 tons which provides $59 \mathrm{~kg}$ of Urea per annum. As a result, the GWP for manufacturing similar amounts of chemical N, P, and $\mathrm{K}$ fertilizer is 15.031 tons $\mathrm{CO}_{2} \mathrm{eqv}$. for the complete sample of biogas-user households. Furthermore, bio-slurry provides accessible plant nutrients faster than fresh manure. In addition, both major and micronutrients are present in bio-slurry and are essential for plant growth (Barbosa et al., 2014). Unfortunately, the farmers used it without proper knowledge about managing and using slurry.

\subsection{3 $\mathrm{CO}_{2}$ Emissions from Biomass Combustion and LPG as Fuel}

The main problem of rural areas is traditional biomass is burned directly for cooking which usually segregates $\mathrm{CO}_{2}$ in the atmosphere. Firewood, residue, and cow dung are the primary source of energy for cooking in the considered areas. The utilization of biogas energy is capable to decrease conventional biomass and non-renewable fuel consumption, and in turn, emissions of GHGs. Using equations 4 and 5, the amount of fuel consumption was calculated by taking the carbon emission factors of $0.45,0.4$, and 0.24 for firewood, dung, and LPG respectively (Pei-dong et al., 2007; Shane and Gheewala, 2017). The average GHG emissions from using firewood, cow dung, residue, and LPG was 122.48 tons, 47.33 tons, 50.22 tons, and 0.963 tons of $\mathrm{CO}_{2}$ eq respectively, which were estimated considering the replacement proportion of biomass fuels with the biogas produced by the 70 digesters, and thus the total amount was 221 tons $\mathrm{CO}_{2}$ eq (Figure 1). 


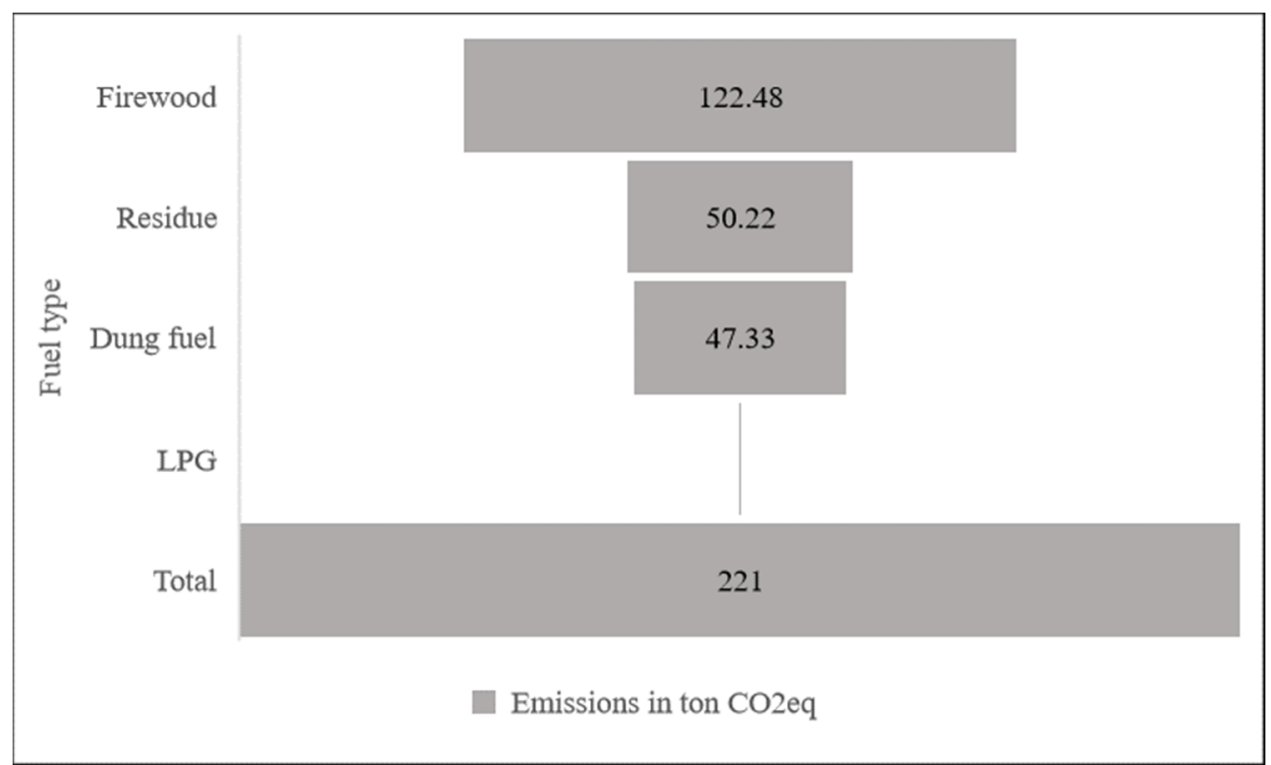

Figure 1. Average GHG emissions per year in ton $\mathrm{CO}_{2}$ eq from various fuels utilized by biogas-users

The use of biogas energy instead of traditional biomass fuels alone reduces GHG emissions on average of 3.1 tons of $\mathrm{CO}_{2} \mathrm{e}$ yearly. The obtained value is lower than the findings of Katuwal and Bohara (2009) (4.5 ton), Laramee and Davis (2013) (6.4 ton), and Pathak et al. (2009) (9.7 ton) but higher than that of Zhang et al. (2013) (1.3 ton). The justification for these dissimilarities could be the absence of country-specific emission factors. The other explanation could be linked to the building materials required for biogas start-up as well as the current state of fuel consumption. Notable that, maximum households had used remaining cow dung in cropland and that dung was stored in a pit whereas it emitted GHG regularly is avoided because there are no available measurement materials in our country.

Furthermore, in addition to reducing GHG emissions from cooking fuel, users were asked about the social welfare attained as a result of the BT introduction vs their previous experience during the survey. They replied that BT improves health conditions by reducing smoke in the kitchen since it takes the place of a typical stove for cooking. Therefore, it could reduce eye or respiratory diseases as well as reduce indoor air pollution.

Biogas energy helps the turndown of woody biomass by replacing the consumption of wood fuel and other household energy sources. A small-scale biogas plant reduces $1217.83 \mathrm{~kg}$ of wood fuel per year. Therefore, the annual potentiality of wood fuel replacement of entire sample biogas digesters is 85.24 tons which indirectly can save the country from deforestation.

\subsubsection{Life Cycle of GHG Emission Reduction}

The GHG emission reduction owing to the use of BT in the studied areas was calculated using equation (6). 


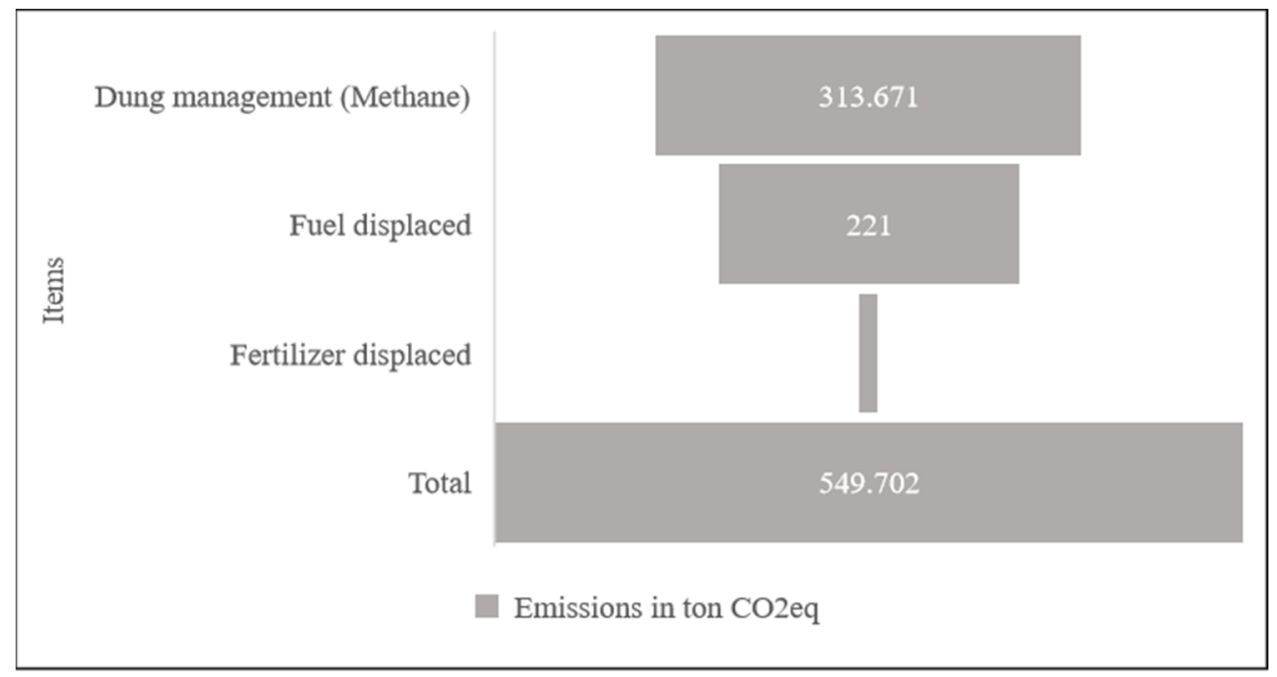

Figure 2. Average annual GHG emissions in ton $\mathrm{CO}_{2}$ eq from total (70) sample biogas plant

The amount of cow dung management and the displacement of chemical fertilizer and fuel were all factors in the calculation of GHG emissions. The methane emitted as a result of leakage during anaerobic digestion is not credited; rather, it is deducted as emission from the system. About 549.702 tons of $\mathrm{CO}_{2} \mathrm{e}$ has been reduced annually from 70 biogas digesters (Figure 2). Therefore, the small-scale biogas plant mitigated 7.8 tons of $\mathrm{CO}_{2} \mathrm{e}$ annually in the studied sites.

\subsubsection{Potentiality of GHG Mitigation in Bangladesh}

There are different biogas digesters established in Bangladesh ranging from $2.0 \mathrm{~m}^{3}$ to $4.8 \mathrm{~m}^{3}$. The daily rated biogas production capacity is different for each of them. According to IRENA (2016), a $2.0 \mathrm{~m}^{3}, 2.4 \mathrm{~m}^{3}, 3.2 \mathrm{~m}^{3}$, and $4.8 \mathrm{~m}^{3}$ biogas digester can produce $0.7 \mathrm{~m}^{3}, 1.2 \mathrm{~m}^{3}, 2.8 \mathrm{~m}^{3}$, and $9.65 \mathrm{~m}^{3}$ biogas per day respectively. So, it is estimated that $2.0 \mathrm{~m}^{3}, 3.2 \mathrm{~m}^{3}$, and $4.8 \mathrm{~m}^{3}$ biogas digester can reduce 4.8 tons, 17.1 tons, and 61.2 tons $\mathrm{CO}_{2} \mathrm{e}$ per annum respectively.

Table 4. Average annual GHG emissions in ton $\mathrm{CO}_{2}$ eq from different sizes of the biogas digester

\begin{tabular}{lllll}
\hline Items & \multicolumn{3}{l}{ Biogas Digester } \\
\cline { 2 - 5 } & $2.0 \mathrm{~m}^{3}$ & $2.4 \mathrm{~m}^{3}$ & $3.2 \mathrm{~m}^{3}$ & $4.8 \mathrm{~m}^{3}$ \\
\hline Cow dung management (Methane) & 2.6 & 4.48 & 10.456 & 35.036 \\
Chemical fertilizer displaced & 0.077 & 0.214 & 0.375 & 0.75 \\
Fuel displaced & 2.14 & 3.1 & 6.27 & 25.38 \\
Total & 4.82 & 7.8 & 17.1 & 61.2 \\
\hline
\end{tabular}

According to a report by IDCOL (there, 100000 domestic biogas plants are running in Bangladesh. As 7.8 tons $\mathrm{CO}_{2} \mathrm{e}$ is reduced by a single digester per annum, it is estimated that an annual average of 78000 tons $\mathrm{CO}_{2} \mathrm{e}$ is mitigating by domestic BT in Bangladesh. Therefore, Bangladesh can contribute to reducing global warming to a large extent by increasing the domestic biogas users through over the country.

\subsection{Economic Analysis}

\subsubsection{Benefit-cost Analysis}

A BCR was calculated for BT plants at the three distinct levels of usefulness; benefits of fuel replacement, fertilizer substitution, and carbon trading. Considering the energy mix of the studied areas, a $2.4 \mathrm{~m}^{3}$ biogas digester can replace $1217.83 \mathrm{~kg}$ of wood fuel, $541.88 \mathrm{~kg}$ of cow dung, and $589.71 \mathrm{~kg}$ of residues in a year. We have done the NPV analysis of the decision on investing in the biogas plant that considers the costs of digester construction, expenditure on biomass, and the procurement cost of fertilizer. Other potential benefits of bio-digester installation, 
such as increased farm income, health improvements, and surplus time were not included in the analysis.

Table 5. Cost-benefit analysis of small-scale biogas plants

\begin{tabular}{ll}
\hline Items & Biogas digester $\left(2.4 \mathrm{~m}^{3}\right)$ \\
\hline Average investment cost & 36032 \\
Average annual current cost & \\
$\bullet \quad$ Depreciation cost & 1441 \\
$\bullet \quad$ Cow dung cost & 2890.8 \\
$\bullet \quad$ Maintenance cost & 1441 \\
Total cost & 5772.8 \\
Average annual current benefits & \\
$\bullet \quad$ Fuel replacement & 13023 \\
$\bullet \quad$ Chemical fertilizers displaced & 3085 \\
Total benefits & 16108 \\
BCR & 1.74 \\
NPV & 50128.44 \\
PBP (year) & 2.53 \\
\hline
\end{tabular}

Note. All the units of the benefits and costs are in Bangladeshi taka (BDT). The currency conversion rate was considered (1USD 84 BDT) as in the year 2019. Maintenance and depreciation costs account for $4 \%$ of investment costs.

The economics of a biogas plant is characterized by a high investment cost, some operating and maintenance costs, mostly free raw materials, income generation from gas production, and earning foreign currency. The investment costs covered the major part of the total cost of a biogas plant. The average investment cost of the household biogas plant (total volume $3 \mathrm{~m}^{3}$ ) was BDT 36032. It is also estimated that the average investment cost of a small-scale biogas plant in study areas was about USD 428.9 (1 USD=84 BDT) while for Pakistan, Nepal, Vietnam, China, Rwanda, Tanzania, and Kenya was estimated to be 426, 547,480, 293, 1306, 780 and 787 USD, respectively (Von Eije, 2012).

The findings estimated BCR with the discount rate of $12 \%$, interest paid to the NGOs at $8 \%$ for up to 24 installments monthly, and a lifespan of 15 years for a plant. Similarly, Von Eije (2012) and Haque (2013) used the duration of constructed biogas digesters of up to 15 years in Bangladesh where and Walekhwa et al. (2009) considered the duration of a biogas plant to be 20 years in India and Uganda. The lifespan of a biogas pant often varies with construction materials, weather, soil structure, input uses, etc. The BCR of the $2.4 \mathrm{~m}^{3}$ biogas digester was 1.74 (Table 5), showing that the plant is cost-effective and provides sufficient advantages to cover expenditures which indicates that the biogas plant is financially viable. (Gabisa and Gheewala (2019)) estimated BCR which was 1.8 for $8 \mathrm{~m}^{3}$ biogas plants in Ethiopia. This variation occurred due to the size of the biogas plant, the price of cooking fuel and chemical fertilizer, and other operating and maintenance costs.

\subsubsection{Estimation of economic evaluation}

The CDM is one of the flexible mechanisms defined in the Kyoto Protocol (IPCC, 2007) that provides for emissions reduction projects which generate certified emission reduction (CER) units that may be traded in emissions trading schemes. Bangladesh has succeeded very little in accruing CDM benefits. It lacked robust institutional mechanisms to submit emissions reduction projects to the UNFCCC in generating CER. Due to the volatility in price linked with the recent global economic recession, the carbon market is yet to reap the benefit of $\mathrm{CDM}$ projects. It has been estimated in this study that a small-sized biogas plant can reduce on an average 7.8 tons $\mathrm{CO}_{2}$ emission, and would earn 6300 BDT per year, with the price of reduction charged at USD 10 per ton $\mathrm{CO}_{2} \mathrm{eq}$ according to the World Bank's State and Trends of Carbon Pricing 2018 (World Bank, 2018). 
Table 6. NPV, BCR, and PBP of a small-scale biogas plant under carbon trading

\begin{tabular}{ll}
\hline Items & Biogas digester $\left(2.4 \mathrm{~m}^{3}\right)$ \\
\hline NPV (BDT) & 62121.71 \\
BCR & 1.9 \\
PBP (year) & 2 \\
\hline
\end{tabular}

The NPV, BCR, and PBP of a biogas plant with carbon trading were BDT 62121.71, 1.9, and 2 years respectively (Table 6), which indicates that adding carbon emission price in total benefits is economically viable for the society. Katuwal and Bohara (2009) also provided a successful economic benefit to the country through reduced deforestation and carbon trading. Even, Adeoti et al. (2000) showed that the $6.0 \mathrm{~m}^{3}$ family-sized biogas project using cow dung as a substrate in Nigeria has good economic potential. However, Haryanto et al. (2017) reported that a family-scale biogas digester using cow dung in Indonesia demonstrated a lot of promise for reducing GHG emission, but it was not economical. This difference from various factors that affect results such as production capacity of biogas, the potential use of biogas, economic condition, measurement unit, etc.

However, our overall findings expressed that the biogas plant is a cost-effective and economically viable technology. Most people could easily adapt to this technology and gained more facilities from the biogas plant.

\subsubsection{Sensitivity Analysis}

Sensitivity analysis is a method for determining how sensitive an analysis' conclusions are to the assumptions used; that is, whether or not the results change significantly when the assumptions are changed. For example, the discount rate's value, the assumption of steady fixed relative prices, life span, and so on. A sensitivity study was conducted for this project, which included a $10 \%$ increase in expenses and a 10\% drop in benefits. A $10 \%$ increase in costs and a $10 \%$ reduction in benefits is based on the assumption that benefits may be reduced by $10 \%$ in the future due to any change, such as an increase in capital costs due to inflation, the implementation of new taxes by the government, an increase in daily labor wages and/or an increase in supply or any other input costs, and so on. It may differ from one field to the next and from one analysis to another. Furthermore, we want to see if such an increment will sustain a positive BCR. Just to keep a cushion for any such change (if occurs) and to sensitize the estimation.

Table 7. Sensitivity analysis of BCR of biogas plants

\begin{tabular}{lllll}
\hline Assumptions & Analysis & $\begin{array}{l}\text { NPV } \\
(\mathrm{BDT})\end{array}$ & BCR & $\begin{array}{l}\text { PBP } \\
\text { (year) }\end{array}$ \\
\hline $\begin{array}{l}\text { Life span } 10 \text { years } \\
\text { Discount rate } 12 \% \\
10 \% \text { rise in cost }\end{array}$ & Financial & 19299.57 & 1.28 & 3.19 \\
$\begin{array}{l}10 \% \text { rise in benefits } \\
\text { Life span } 15 \text { years }\end{array}$ & Economic & 28345.80 & 1.41 & 2.94 \\
$\begin{array}{l}\text { Discount rate } 12 \% \\
10 \% \text { rise in cost }\end{array}$ & Financial & 31630.98 & 1.42 & 3.19 \\
$\begin{array}{l}10 \% \text { rise in benefits } \\
\text { Life span } 15 \text { years }\end{array}$ & Economic & 42424.93 & 1.57 & 2.94 \\
$\begin{array}{l}\text { Discount rate } 20 \% \\
10 \% \text { rise in cost }\end{array}$ & Financial & 8800.25 & 1.14 & 3.4 \\
$10 \%$ rise in benefits & & & & \\
\hline
\end{tabular}

Table 7 demonstrates that the BCR values for all assumptions are still larger than 1. Biogas plants' BCR varies, indicating that they will be able to generate enough benefits to pay costs even if their costs rise and their benefits fall. In addition, the values of NPV, and PBP state that the biogas plant is still not only financially but also 
economically viable.

\section{Conclusions}

The biogas plant technology is an alternate energy source that can play a major role in reducing GHG emissions by substituting fresh cow dung, cooking fuel, and chemical fertilizer. The replacement of traditional biomass fuels with biogas energy reduces on average 3.1 tons of $\mathrm{CO}_{2} \mathrm{e}$. This study also assists in calculating the GHG emission from LPG burning and chemical fertilizer use in croplands. The bio-slurry substitutes $59 \mathrm{~kg}$ of N, $42 \mathrm{~kg}$ of P, and $33 \mathrm{~kg}$ of K fertilizer, respectively per annum, which produces $214.73 \mathrm{~kg} \mathrm{CO}_{2} \mathrm{e}$ per digester. When compared to conventional manure, bio-slurry provides better quality fertilizer in terms of least accessible nitrogen fertilizer. It provides more nutrients to the soil and can save the soil from erosion. The economic aspects of the biogas technology in the studied sites are also discussed. The biogas system's NPV, BCR, and PBP have been studied. The values were positive that indicated that small-scale biogas plant is not only environmental friendly but also economically viable technology. With proper management and performance of a large number of existing and potential biogas plants, Bangladesh has a good opportunity to solve its energy crisis, reduce global warming and earn substantial revenue under the new regime of carbon marketing.

\section{Acknowledgments}

National Science and Technology (NST) Fellowship supported this conducted work. We are thankful to Aurup Ratan Dhar, Dept. of Environmental and Energy Economics at Tohoku University Japan, for helpful feedback on earlier versions of this work; IDCOL and Grameen Shakti in Bangladesh for assistance with organizing the household's interview. Finally, we are highly thankful to the respondents of the study area for their valuable time and support during data collection.

\section{References}

Abbas, M. (2013). Biogas production from municipal organic waste, a process of sustainable development in Lahore (a review). (Thesis, Department of International Environment and Development Studies, Norwegian University of Life Sciences, Norway). Retrieved from https://nmbu.brage.unit.no/nmbuxmlui/bitstream/handle/11250/187923/thesis\%20final\%20Copy\%2016.12.13.pdf?sequence=1\&isAllowed= $\mathrm{y}$

Abbas, T., Ali, G., Adil, S. A., Bashir, M. K., \& Kamran, M. A. (2017). Economic analysis of biogas adoption technology by rural farmers: The case of Faisalabad district in Pakistan. Renewable Energy, 107, 431-439. https://doi.org/10.1016/j.renene.2017.01.060

Adeoti, O., Ilori, M. O., Oyebisi, T. O., \& Adekoya, L. O. (2000). Engineering design and economic evaluation of a family-sized biogas project in Nigeria. Technovation, 20, 103-108. https://doi.org/10.1016/S01664972(99)00105-4

Ahiduzzaman, M., \& Islam, A. K. M. S. (2011). Greenhouse gas emission and renewable energy sources for sustainable development in Bangladesh. Renewable and Sustainable Energy Reviews, 15, 4659-4666. https://doi.org/10.1016/j.rser.2011.07.086

Ahuja, D., \& Tatsutani, M. (2009). Sustainable energy for developing countries. Surveys and Perspectives Integrating Environment and Society (SAPIENS), 2. Retrieved from https://journals.openedition.org/sapiens/823

Amare, Z. Y. (2014). The role of Biogas Energy Production and Use in Greenhouse Gas Emission Reduction; the case of Amhara National Regional State, Fogera District, Ethiopia. Journal of Multidisciplinary Engineering Science and Technology (JMEST), 1, 404-410.

Amin, S. B. (2015). The macroeconomics of energy price shocks and electricity market reforms: The case of Bangladesh. Durham thesis, Durham University. Retrieved from http://etheses.dur.ac.uk/11241/.

Amin, S. B., \& Rahman, S. (2019). Biogas generation from household Level farming in Bangladesh. Energy Resources in Bangladesh. Springer, pp. 113-116.

Barbosa, D. B. P., Nabel, M., \& Jablonowski, N. D. (2014). Biogas-digestate as nutrient source for biomass production of Sida hermaphrodita, Zea mays L. and Medicago sativa L. Energy Procedia, 59, 120-126. https://doi.org/10.1016/j.egypro.2014.10.357

Baul, T. K., Datta, D., \& Alam, A., (2018). A comparative study on household level energy consumption and related emissions from renewable (biomass) and non-renewable energy sources in Bangladesh. Energy Policy, 114, 598-608. https://doi.org/10.1016/j.enpol.2017.12.037 
Bentzen, J., Truc, N. T. T., \& Nam, T. S. (2018). A social cost-benefit analysis of biogas technologies using rice Straw and water hyacinths as feedstock. International Energy Journal, 18, 311-320.

Bruun, S., Jensen, L. S., \& Sommer, S. (2014). Small-scale household biogas digesters: An option for global warming mitigation or a potential climate bomb? Renewable and Sustainable Energy Reviews, 33, 736-741. https://doi.org/10.1016/j.rser.2014.02.033

Ding, W., Niu, H., Chen, J., Du, J., Wu, Y. (2012). Influence of household biogas digester use on household energy consumption in a semi-arid rural region of northwest China. Applied Energy, 97, 16-23. https://doi.org/10.1016/j.apenergy.2011.12.017

Feng, T., Cheng, S., Min, Q., \& Li, W. (2009). Productive use of bioenergy for rural household in ecological fragile area, Panam County, Tibet in China: the case of the residential biogas model. Renewable and Sustainable Energy Reviews, 13, 2070-2078. https://doi.org/10.1016/j.rser.2009.02.001

Foysal, M. A., Hossain, M. L., Rubaiyat, A., Sultana, S., Uddin, M. K., Sayem, M. M., \& Akhter, J. (2012). Household energy consumption pattern in rural areas of Bangladesh. Indian Journal of Energy, 1, 72-85.

Gabisa, E. W., \& Gheewala, S. H. (2019). Potential, environmental, and socio-economic assessment of biogas production in Ethiopia: The case of Amhara regional state. Biomass and Bioenergy, 122, 446-456. https://doi.org/10.1016/j.biombioe.2019.02.003

Gaur, A. (1992). Bulky organic manures and crop residues, Fertilisers, organic manures, recyclable wastes and biofertilisers: Components of integrated plant nutrition. edited by H. Tandon. New Dehli: Fertiliser Development and Consultation Organisation.

Gautam, R., Baral, S., \& Herat, S. (2009). Biogas as a sustainable energy source in Nepal: Present status and future challenges. Renewable and Sustainable Energy Reviews, 13, 248-252. https://doi.org/10.1016/j.rser.2007.07.006

Ghimire, P. C. (2005). National program on domestic biogas in Bangladesh. Report, SNV (Netherlands Development Organization) and IDCOL (Infrastructure Development Company Ltd.).

Gofran, M. A. (2004). The Role of Grameen Shakti in biogas program in Bangladesh: A concept paper on biogas. Biogas Extension Program organized by Grameen Shakti, Dhaka, Bangladesh. December 24, 2004.

Haque, A. (2013). Bioslurry ultimate choice of biofertilizer. Open Access Scientific Reports, 2, 1-8. Retrieved from https://www.omicsonline.org/scientific-reports/JBES-SR-738.pdf

Haryanto, A., Cahyani, D., Triyono, S., Murdapa, F., \& Haryono, D. (2017). Economic benefit and greenhouse gas emission reduction potential of a family-scale cowdung anaerobic biogas digester. International Journal of Renewable Energy Development, 6(1), 29-36.

Hou, J., Zhang, W., Wang, P., Dou, Z., Gao, L., \& Styles, D. (2017). Greenhouse gas mitigation of rural household biogas systems in China: A life cycle assessment. Energies, 10(2), 239. http://dx.doi.org/10.3390/en10020239

Hutton, G., Rehfuess, E., \& Tediosi, F. (2007). Evaluation of the costs and benefits of interventions to reduce indoor air pollution. Energy for Sustainable Development, 11, 34-43. https://doi.org/10.1016/S09730826(08)60408-1

IDCOL. (2017). The National Domestic Biogas and Manure Programme (NDBMP): Implementation plan. Infrastructure Development Company Limited. Kawran Bazar, Dhaka-1215, Bangladesh.

IEA. (2010). Oil Information. International Energy Agency, Paris. Retrieved March 28, 2019, from http://wds.iea.org/wds/pdf/documentation_oil.pdf

IPCC. (2006). IPCC (Intergovernmental Panel on Climate Change) Guidelines for National Greenhouse Gas Inventories. Institute for Global Environmental Strategies (IGES), Hayama, Japan.

IPCC. (2007). Climate change 2007: the physical science basis, in: Contribution of Working Group I to the $4^{\text {th }}$ Assessment Report of the Intergovernmental Panel on Climate Change. Cambridge University Press, Cambridge and New York.

Iqbal, S. A., Rahaman, S., \& Yousuf, A. (2014). Present scenario of biogas technology in Bangladesh-prospects, potentials and barriers. Proceedings of the $15^{\text {th }}$ annual paper meet 7 , 08. Retrieved from https://www.researchgate.net/publication/273140048_present_scenario_of_biogas_technology_in_banglade sh-prospects_potentials_and_barriers 
IRENA. (2016). Measuring small-scale biogas capacity and production. International Renewable Energy Agency, Abu Dhabi. Retrieved from https://www.irena.org/publications/2016/Dec/Measuring-small-scale-biogascapacity-and-production

Junior, J. F. S., \& Bank, W. (2017). Industrial Processing Integration of Alcohol and Sugar Production, Cogeneration of Electricity. Elsevier.

Kabir, H., Palash, M. S., \& Bauer, S. (2012). Appraisal of domestic biogas plants in Bangladesh. Bangladesh Journal of Agricultural Economics, 35, 71-89. Retrieved from https://www.researchgate.net/publication/315814521_Appraisal_of_Domestic_Biogas_Plants_in_Banglade sh

Katuwal, H., \& Bohara, A. K., (2009). Biogas: A promising renewable technology and its impact on rural households in Nepal. Renewable and Sustainable Energy Reviews, 13, 2668-2674. https://doi.org/10.1016/j.rser.2009.05.002

Khan, E. U., \& Martin, A. R. (2016). Review of biogas digester technology in rural Bangladesh. Renewable and Sustainable Energy Reviews, 62, 247-259. https://doi.org/10.1016/j.rser.2016.04.044

Khan, E. U., Mainali, B., Martin, A., \& Silveira, S. (2014). Techno-economic analysis of small scale biogas based polygeneration systems: Bangladesh case study. Sustainable Energy Technologies and Assessments, 7, 6878. https://doi.org/10.1016/j.seta.2014.03.004

Kinyua, M. N., Rowse, L. E., \& Ergas, S. J. (2016). Review of small-scale tubular anaerobic digesters treating livestock waste in the developing world. Renewable and Sustainable Energy Reviews, 58, 896-910. https://doi.org/10.1016/j.rser.2015.12.324

Lansche, J., Schock, S., \& Müller, J. (2011). Life cycle assessment on the substitution of dung combustion by biogas systems in Ethiopia. International Research on Food Security, Natural Resource Management and Rural Development, University of Bonn.

Laramee, J., \& Davis, J. (2013). Economic and environmental impacts of domestic bio-digesters: Evidence from Arusha, Tanzania. Energy for Sustainable Development, 17, 296-304. https://doi.org/10.1016/j.esd.2013.02.001

Mainali, B., Emran, S.B., Silveira, S. (2017). Greenhouse gas mitigation using poultry litter management techniques in Bangladesh. Energy, 127, 155-166. https://doi.org/10.1016/j.energy.2017.03.103

Mengistu, M. G., Simane, B., Eshete, G., \& Workneh, T. S. (2016). The environmental benefits of domestic biogas technology in rural Ethiopia. Biomass and Bioenergy, 90, 131-138. https://doi.org/10.1016/j.biombioe.2016.04.002

Pathak, H., Jain, N., Bhatia, A., Mohanty, S., \& Gupta, N. (2009). Global warming mitigation potential of biogas plants in India. Environmental Monitoring and Assessment, 157, 407-418. https://doi.org/10.1007/s10661008-0545-6

Pei-dong, Z., Guomei, J., \& Gang, W. (2007). Contribution to emission reduction of $\mathrm{CO}_{2}$ and $\mathrm{SO} 2$ by household biogas construction in rural China. Renewable and Sustainable Energy Reviews, 11, 1903-1912. https://doi.org/10.1016/j.rser.2005.11.009

Rahman, K. M., Melville, L., Fulford, D., \& Huq, S. M. I. (2017). Green-house gas mitigation capacity of a small scale rural biogas plant calculations for Bangladesh through a general life cycle assessment. Waste Management and Research, 35, 1023-1033. https://doi.org/10.1177\%2F0734242X17721341

Rahman, K. M., Woodard, R., Manzanares, E., \& Harder, M. K., (2014). An assessment of anaerobic digestion capacity in Bangladesh. Renewable and Sustainable Energy Reviews, 32, 762-769. https://doi.org/10.1016/j.rser.2014.01.026

Rahman, M. A., Møller, H. B., \& Alam, M. M. (2018). Assessing the energy potential of agricultural residues and an approach to meet the rural energy demand: the Bangladesh perspective. Biomass Conversion and Biorefinery, 8, 925-934.

Rajendran, K., Aslanzadeh, S., \& Taherzadeh, M. J. (2012). Household biogas digesters-A review. Energies, 5 , 2911-2942. https://doi.org/10.3390/en5082911

Salam, M. A., Ahmed, K., Akter, N., Hossain, T., \& Abdullah, B. (2018). A review of hydrogen production via biomass gasification and its prospect in Bangladesh. International Journal of Hydrogen Energy, 43(32), 14944-14973. https://doi.org/10.1016/j.ijhydene.2018.06.043 
Shane, A., \& Gheewala, S. H. (2017). Missed environmental benefits of biogas production in Zambia. Journal of Cleaner Production, 142, 1200-1209. https://doi.org/10.1016/j.jclepro.2016.07.060

TERI. (2001). Energy Data Directory and Yearbook, 2000-01. Tata Energy Research Institute, New Delhi: TERI Press.

Uddin, S. N., \& Taplin, R. (2006). A sustainable energy future in Bangladesh: current situation and need for effective strategies. Proceedings of the second joint international conference on sustainable energy and environment, SEE, p. e3.

Uma, T. (2014). Investigation of environmental and economic benefits of bioslurry from coffee husk relative to chemical fertilizer. MS thesis, School of Graduate Studies. Addis Ababa University. Retrieved from http://etd.aau.edu.et/handle/123456789/11897

Von Eije, S. (2012). Financial and economic performance of domestic biogas installations: Not making money, still getting rich? Training Program on Compact Biogas Course During, pp. 10-13.

Walekhwa, P. N., Mugisha, J., \& Drake, L. (2009). Biogas energy from family-sized digesters in Uganda: critical factors and policy implications. Energy Policy, 37, 2754-2762. https://doi.org/10.1016/j.enpol.2009.03.018

World Bank., (2018). World Bank's State and Trends of Carbon Pricing. Washington DC. Retirved May 20, 2019, from https://openknowledge.worldbank.org/bitstream/handle/10986/29687/9781464812927.pdf?sequence=5\&is Allowed=y; 2018

Yu, L., Yaoqiu, K., Ningsheng, H., Zhifeng, W., \& Lianzhong, X. (2008). Popularizing household-scale biogas digesters for rural sustainable energy development and greenhouse gas mitigation. Renewable Energy, 33, 2027-2035. https://doi.org/10.1016/j.renene.2007.12.004

Zhang, L. X., Wang, C. B., \& Song, B. (2013). Carbon emission reduction potential of a typical household biogas system in rural China. Journal of Cleaner Production, 47, 415-421. https://doi.org/10.1016/j.jclepro.2012.06.021

\section{Copyrights}

Copyright for this article is retained by the author(s), with first publication rights granted to the journal.

This is an open-access article distributed under the terms and conditions of the Creative Commons Attribution license (http://creativecommons.org/licenses/by/4.0/). 